\title{
ZMIANA POZYCJI KORPORACJI TRANSNARODOWYCH W GOSPODARCE ŚWIATOWEJ - IMPLIKACJE DLA MIĘDZYNARODOWYCH RYNKÓW FINANSOWYCH
}

\begin{abstract}
Streszczenie. W artykule przedstawiono ewolucję korporacji transnarodowych i konsekwencje ich rosnącej roli w gospodarce światowej. Podjęto próbę oceny wpływu tych zmian na globalne przepływy kapitału oraz konsekwencje tego faktu dla międzynarodowych rynków finansowych. Artykuł składa się z trzech części. Część pierwsza - ewolucja korporacji transnarodowych jako podstawa uzyskania silnej pozycji w gospodarce światowej. Część drugiej - analiza potencjału najpotężniejszych korporacji transnarodowych na tle PKB państw oraz wartości globalnego rynku kapitałowego. Część trzecia - próba oceny wpływu korporacji na międzynarodowe przepływy kapitału i funkcjonowanie rynków finansowych.
\end{abstract}

Słowa kluczowe: korporacje transnarodowe, KTN, globalizacja, bezpośrednie inwestycje zagraniczne, BIZ, inwestycje portfelowe, gospodarka światowa.

\section{WPROWADZENIE}

Celem artykułu jest próba zwrócenia uwagi na rosnącą rolę korporacji transnarodowych (KTN) w gospodarce światowej i konsekwencje tego faktu dla kreowania globalnych przepływów kapitałowych. Tezą artykułu jest, że wzrost siły kapitałowej KTN powoduje niejako automatyczny spadek siły oraz zakresu możliwości oddziaływania państw na rynek finansowy, a w efekcie wzrost wrażliwości realnej gospodarki na impulsy i „zawirowania” w świecie finansów międzynarodowych. Korporacje, dysponując aktywami przekraczającymi globalne PKB, decydują w znacznej mierze o strukturze obrotów we współczesnej gospodarce i kierunkach przepływów. Znacząco wpływają zatem swoimi decyzjami na obraz międzynarodowych rynków finansowych, stając się na nich istotnymi graczami.

Artykuł podzielono na trzy części. W pierwszej zaprezentowano ewolucję korporacji transnarodowych, etapy ich rozwoju i budowania pozycji. W drugiej części przedstawiono analizę potencjału najpotężniejszych korporacji transnarodowych pod kątem jego oceny na tle PKB państw oraz wartości globalnego ryn-

* Uniwersytet Łódzki, Wydział Ekonomiczno-Socjologiczny, Katedra Międzynarodowych Stosunków Gospodarczych. 
ku kapitałowego, wykorzystując World Investment Report oraz Global Financial Stability Report. W ostatniej części artykułu podjęto próbę oceny wpływu zmian siły korporacji transnarodowych i ich pozycji w gospodarce światowej na międzynarodowe przepływy kapitału i funkcjonowanie rynków finansowych.

\section{EWOLUCJA KORPORACJI TRANSNARODOWYCH - ETAPY ROZWOJU I BUDOWANIA POZYCJI W GOSPODARCE ŚWIATOWEJ}

Panuje dość powszechna opinia, że korporacje transnarodowe to główni beneficjenci zmian zachodzących w gospodarce światowej. Wskazuje się, że są to podmioty będace liderami przemian gospodarczych, które decydują o ich kierunkach, dlatego ze wszelkich kryzysów finansowych wychodzą coraz silniejsze. Przypisuje się im zdolność przełamywania dotychczasowych barier zarówno w sferze międzynarodowej wymiany towarowej, jak i w sferze obrotu finansowego (Boruc, Remisewicz 1999: 62). Wynika to z faktu, że KTN doskonale rozpoznały uwarunkowania i wymogi rozwojowe w dynamicznie ewoluującej gospodarce światowej. W efekcie dostosowują się do nich lepiej i szybciej niż inni uczestnicy rynków międzynarodowych. Za nimi stoi logika procesów globalizacji, uwalniająca siły rynkowe od barier, dająca szansę prowadzenia rozproszonej w sensie geograficznym i zintegrowanej w wymiarze funkcjonalnym działalności (Piórko 2008: 5).

W oparciu o ranking największych korporacji transnarodowych na świecie Forbes Global 2000 z 2013 r., uwzględniający ich aktywa, sprzedaż, wartość rynkową i zysk ${ }^{1}$ można stwierdzić, że przedsiębiorstwa te w 2012 r. dysponowały aktywami wartości 149 bln USD (wzrost rok do roku o 8\%), zrealizowały obroty na poziomie 36 bln USD (wzrost o 12\%) oraz zyski na poziomie 2,64 bln USD (wzrost o 11\%). Ich wartość rynkowa to 37 bln USD. W zestawieniu tym znalazły się firmy z 66 najbardziej wpływowych państw świata (w tym 18 członków UE). Najwięcej swoich korporacji w rankingu uplasowały Stany Zjednoczone (524 firmy). Drugie miejsce zajęła pod tym względem Japonia (258 firm). Na kolejnych miejscach znalazły się Chiny (które umocniły swoją pozycję), Korea Południowa, Indie i Wielka Brytania (Gasz 2012: 35-37). Unia Europejska umieściła w rankingu 441 przedsiębiorstw (Forbes Global 2000 2013), co wskazuje, że jako całość reprezentuje ona istotny potencjał. Przywołany ranking wydaje się o tyle ciekawy, że ocenę gospodarek macierzystych przez pryzmat liczby, zasobów i skali działania (w tym inwestycji), pochodzących z nich korporacji jest zabiegiem, który dość często wykorzystuje się jako syntetyczny obraz potencjału poszczególnych gospodarek.

${ }^{1}$ W 2012 r. do ustalenia potencjału największych korporacji przyjęto nową metodologię. Autorzy rankingu odeszli od wcześniejszej metodologii, według której poszczególne kryteria były traktowane oddzielnie. Obecnie cztery podstawowe kryteria: aktywa, sprzedaż, zysk, wartość rynkowa mają jednakową wagę przy określaniu pozycji korporacji. 
Potwierdza to umocnienie międzynarodowej pozycji KTN we współczesnej gospodarce, docenienie ich potencjału rozwojowego i zdolności ekspansji. Korporacje systematycznie budowały swoją pozycję i rozwijały strefy wpływów. Dzięki dostosowywaniu swoich struktur i zasad funkcjonowania do uwarunkowań otoczenia stały się zdolne do uzyskiwania korzyści, wynikających ze specyfiki polityki poszczególnych państw oraz różnic w rozmieszczeniu czynników produkcji: zasobów naturalnych, kapitału, pracy, a obecnie w dobie gospodarki opartej na wiedzy - właśnie wiedzy. Obecnie KTN postrzegane są jako sprawne organizacje, zarządzające globalnie zorganizowaną siecią produkcyjno-usługową oraz kontrolujące znaczne obszary gospodarki poprzez zaangażowanie kapitałowe. Ich działalność utożsamiana jest z globalizacją rynków (w tym finansowych), kształtowaniem głównych strumieni przepływów kapitałowych (zwłaszcza bezpośrednich inwestycji zagranicznych, ale także inwestycji portfelowych), rozwijaniem globalnych systemów produkcji, restrukturyzacją gospodarek narodowych, a przede wszystkim wzrostem współzależności między nimi (KTN) a zmianami w funkcjonowaniu niemal wszystkich sfer życia gospodarczo-społecznego (Rosińska-Bukowska 2012: 17-19).

Określenie „korporacja transnarodowa” weszło do powszechnego użycia w połowie lat 70. XX w. Starano się w ten sposób zwrócić uwagę, że są to podmioty specyficzne, działające poza kontrolą konkretnego państwa i czerpiące korzyści z rozrastających się w skali globalnej struktur. W myśl definicji UNCTAD korporacja transnarodowa to przedsiębiorstwo będące spółką kapitałową (akcyjną lub inną jednostką gospodarczą), składającą się z korporacji-matki (posiadającej kontrolę, nad co najmniej $10 \%$ akcji lub innych udziałów jednostek gospodarczych zlokalizowanych poza krajem pochodzenia) i afiliowanych przy niej przedsiębiorstw zagranicznych w postaci: filii, jednostek zależnych i stowarzyszonych. Wszystkie typy afiliacji są efektem realizacji koncepcji rozwoju strategicznego poprzez angażowanie się korporacji w bezpośrednie inwestycje zagraniczne (w tym fuzje i przejęcia) w celu budowania łańcucha produkcji międzynarodowej (Dunning 2001: 173-190). Powstała struktura pozwala KTN na generowanie globalnej wartości dodanej. Istotne, że nie jest to jedynie kwestia doraźnego obniżania kosztów transakcyjnych, a model rozwoju oparty na kreowaniu wiedzy, która zostaje wykorzystywania do budowania trwałej pozycji w gospodarce światowej (Kogut, Zander 2003: 516-529).

Należy podkreślić, że istnieją przynajmniej dwa podstawowe typy korporacji transnarodowych, czyli spółki niefinansowe związane z tzw. sferą realną (np. korporacje motoryzacyjne, elektroniczne, telekomunikacyjne, petrochemiczne etc.) oraz spółki finansowe, operujące w sektorze finansowym (bankowe, ubezpieczeniowe etc.). $Z$ uwagi na specyfikę ich działalność analizowana jest zazwyczaj osobno. W niniejszym artykule starano się zaakcentować, że oba typy podmiotów równolegle wpływają na zasady funkcjonowania i kierunki rozwoju gospodarki światowej. Ich aktywności stanowią swoisty system naczyń połączonych, dlatego 
błędem wydaje się całkowite rozdzielanie prowadzonych analiz. W celu uzyskania możliwie pełnego obrazu siły oddziaływania korporacji transnarodowych na międzynarodowy rynek finansowy konieczne jest holistyczne ujęcie, obejmujące zmiany w grupie najpotężniejszych finansowych i niefinansowych KTN.

\section{NAJPOTĘŻNIEJSZE KORPORACJE TRANSNARODOWE - W ŚWIETLE RAPORTÓW UNCTAD (W LATACH 1990-2014)}

Początków ekspansji korporacji transnarodowych we współczesnym rozumieniu należy upatrywać w wykorzystaniu szans stworzonych przez rozwoju metod masowej produkcji na bazie zmian technologicznych oraz możliwości intensyfikacji powiązań kapitałowych poprzez uruchamianie bezpośrednich inwestycji zagranicznych (BIZ). Dynamiczny rozwój korporacji rozpoczął się od połowy lat 70. XX w. Do amerykańskich liderów² dołączyły wówczas prężnie rozwijające się korporacje europejskie i japońskie. W latach 1980-1987 ich aktywność inwestycyjna (BIZ) w USA wzrosła o ponad 200\%. Do grona tego systemicznie włączały się ponadto firmy z Chin, Indii, Korei Płd. W latach 1993-2003 liczba chińskich korporacji wzrosła z 379 do 2000, a indyjskich w latach 1991-2004 z 187 do 1700 (Kolka 2010). W efekcie w ciągu pół wieku ogólna liczba korporacji transnarodowych na świecie wzrosła piętnastokrotnie (z 7 tys. podmiotów w 1969 r. do 100 tys. w 2015 r. - wykres 1).

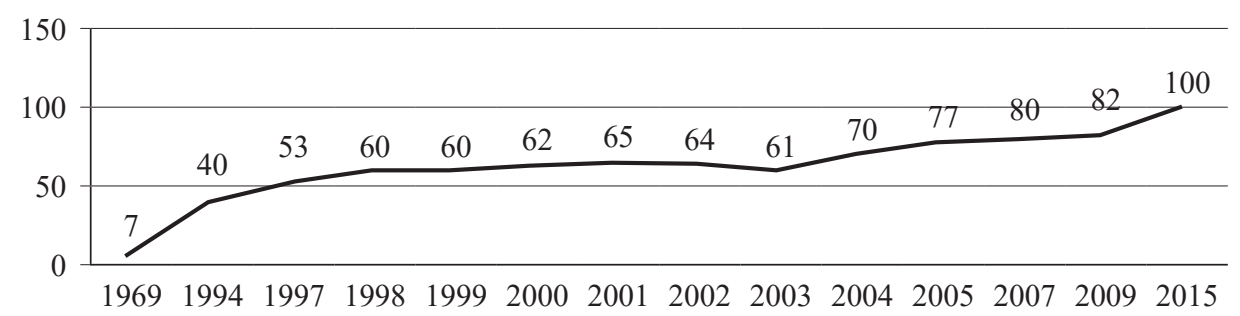

Wykres 1. Liczba korporacji transnarodowych na świecie (w tys.)

Źródło: opracowanie własne na podstawie: Gwiazda (2000: 69-70), World Investment Report (2006: 5; 2005: xix; 2004: xvii; 2003: xiiv; 2002: 1), Zimny (2015: 15).

Tak dynamiczny rozwój korporacji spowodował powstawanie licznych klasyfikacji, dotyczących ich działalności i podejmowanie prób analizy ich oddziaływania na system gospodarki światowej i jego elementy. Jednym z takich raportów jest przygotowany przez Agendę ONZ ds. Handlu i Rozwoju UNCTAD World Investment Report (WIR). Od 1990 r. (dane 1991-2013) przygotowywany jest

\footnotetext{
${ }^{2}$ W tym okresie $70 \%$ największych KTN pochodziło ze Stanów Zjednoczonych.
} 
ranking 100 najpotężniejszych niefinansowych KTN, podający wartości aktywów, sprzedaży oraz wielkości zatrudnienia (ogółem i za granicą), a także wskaźniki skali umiędzynarodowienia działalności. Tak dokładne „prześwietlenie” tej grupy korporacji wynika z faktu, że to im przypisywano rolę głównej siły, wpływającej na gospodarkę światową (handel, inwestycje), a w konsekwencji politykę poszczególnych państw.

Wraz z rozwojem procesów globalizacji rynków i liberalizacji przepływów kapitałowych, czyli zmianami związanymi z wejściem gospodarki w fazę kapitalizmu inwestorskiego (Rosińska-Bukowska 2009: 285-298) dostrzeżono jednak potrzebę pogłębionej analizy także dla korporacji działających w sferze finansowej. W raporcie WIR2004 po raz pierwszy dokonano zestawienia największych banków (według liczby krajów goszczących) oraz najsilniejszych firm ubezpieczeniowych, działających intensywnie na rynku międzynarodowym (ubezpieczenia zagraniczne powyżej 20 mld USD). W tab. 1 przedstawiono pierwszą dziesiątkę w obu kategoriach - porównanie dotyczy ich aktywów w 2002 r., 2006 r. i 2012 r.

$\mathrm{Z}$ przedstawionego $\mathrm{w}$ tab. 1 zestawienia wynika, że potencjał rozwojowych banków rósł znacznie dynamiczniej niż zaliczanych także do sfery finansowej korporacji ubezpieczeniowych. Aktywa 10 banków, które wskazano w 2002 r. jako najpotężniejsze, wzrosły bowiem o $132 \%$, podczas gdy korporacji ubezpieczeniowych jedynie o 21\% (Allianz i AIG wykazały nawet 20\% spadki). Dodatkowo należy zaznaczyć, że niniejsza analiza sektora bankowego dotyczy tylko Top10 z 2002 r. W ciągu dekady swoje struktury rozwinęły jednak kolejne korporacje finansowe (których nie objęła niniejsza analiza), np.: Credit Agricole SA (aktywa w 2012 r. 2429 mld USD), Barclays (aktywa w 2012 r. 2422 mld USD), JP Morgan (aktywa w 2012 r. 2359 mld USD), Bank of America (aktywa w 2012 r. 2210 mld USD), Banco Santander (aktywa w 2012 r. 1677 mld USD) czy Societe General (aktywa w 2012 r. 1649 mld USD). Potwierdza to, że w dobie globalizacji rynków i liberalizacji globalnych przepływów korporacje finansowe (zwłaszcza banki) systematycznie umacniały swoją pozycję w gospodarce światowej.

W raporcie WIR2007 po raz pierwszy znalazł się osobny, kompleksowy ranking 50 najpotężniejszych finansowych KTN (dane za 2005 r.), przedstawiający obok aktywów oraz zatrudnienia danej spółki, $\mathrm{m}$. in. indeks geograficznego rozproszenia filii (GSI) i indeks rozprzestrzenienia sieci (NSI). Wprowadzenie tej klasyfikacji świadczy o dostrzeżeniu rosnącej roli tej grupy korporacji na rynku światowym i konieczności stałego monitorowania ich aktywności jako istotnej dla kształtowania uwarunkowań działania innych podmiotów.

Wykorzystując klasyfikację WIR UNCTAD - tabele The World's Top 100 Non-financial TNCs oraz World's Top 50 Financial TNCs - dokonano porównania zmian aktywów najpotężniejszych finansowych i niefinansowych korporacji transnarodowych w latach 2004-2013. Dodatkowo zestawiono je z podawanymi przez IMF w Global Financial Stability Report wartościami globalnego rynku kapitałowego i globalnego PKB. Na potrzeby niniejszego opracowania przyjęto 
童

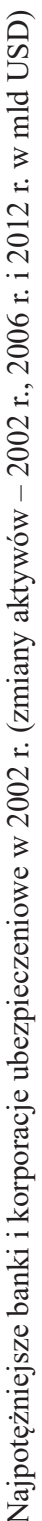

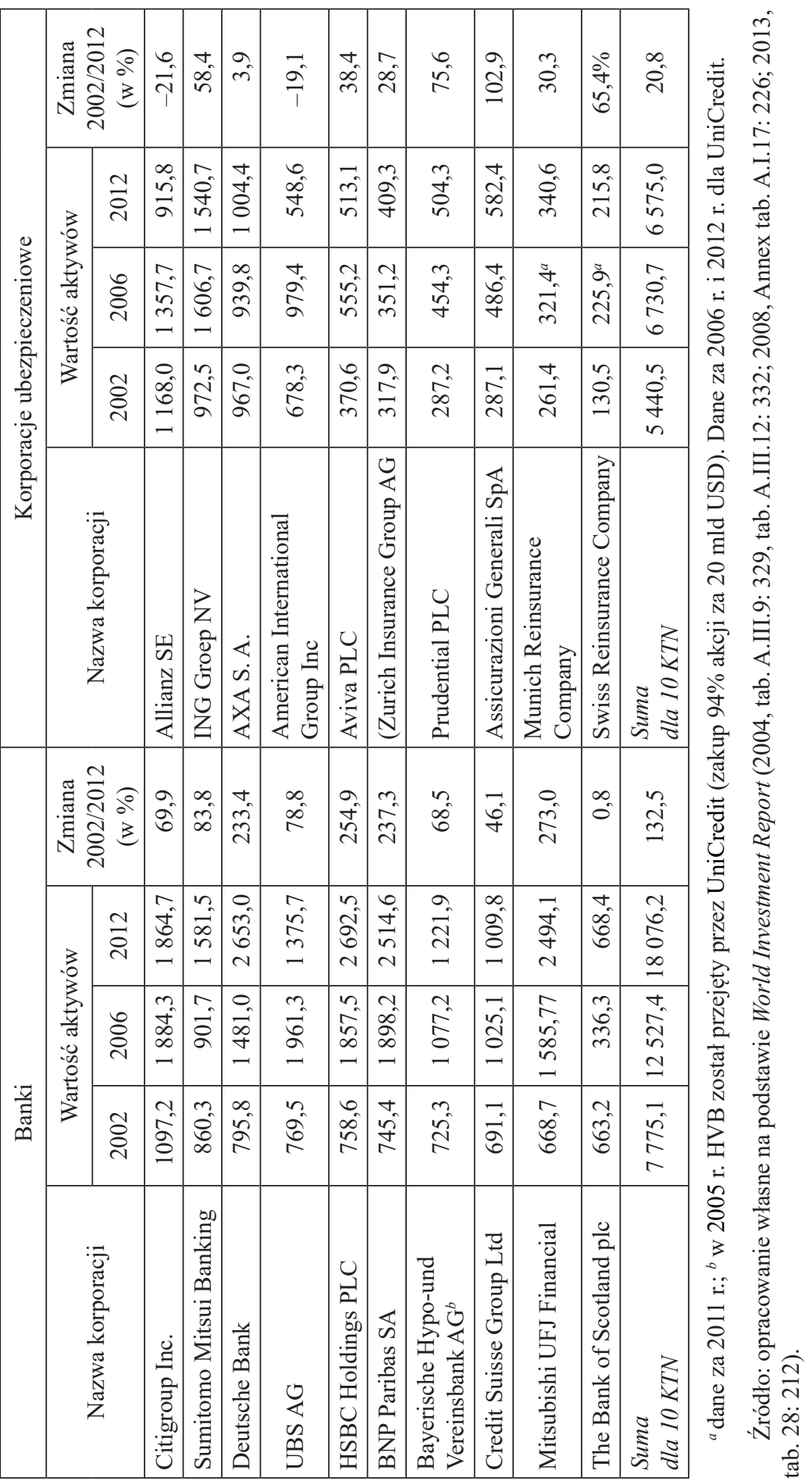


założenie, że udział aktywów finansowych KTN w globalnym rynku kapitałowym oraz udział aktywów niefinansowych KTN w globalnym PKB mogą stanowić uproszczony obraz wpływów korporacji transnarodowych na system gospodarki światowej (tab. 2 i 3 ).

Tabela 2

Aktywa najpotężniejszych KTN (finansowych i niefinansowych) na tle wartości globalnego rynku kapitałowego i globalnego PKB (mld USD)

\begin{tabular}{|c|c|c|c|c|c|}
\hline \multirow{2}{*}{ Rok } & \multirow{2}{*}{$\begin{array}{c}\text { Globalne } \\
\text { PKB }\end{array}$} & \multirow{2}{*}{$\begin{array}{l}\text { Globalny } \\
\text { rynek } \\
\text { kapitałowy }\end{array}$} & \multirow{2}{*}{$\begin{array}{c}\text { Globalne } \\
\text { aktywa } \\
\text { bankowe }\end{array}$} & \multicolumn{2}{|c|}{$\begin{array}{l}\text { Aktywa najpotężniejszych KTN } \\
\text { (według UNCTAD) }\end{array}$} \\
\hline & & & & $\begin{array}{c}50 \mathrm{KTN} \\
\text { finansowych }\end{array}$ & $\begin{array}{c}100 \mathrm{KTN} \\
\text { niefinansowych }\end{array}$ \\
\hline 2013 & 72105,8 & 273768,9 & 121946,5 & - & 13748,3 \\
\hline 2012 & 72216,4 & 268585,2 & 116956,1 & 51002,9 & 12841,5 \\
\hline 2011 & 69899,2 & 255855,6 & 110378,2 & 53779,4 & 12359,8 \\
\hline 2010 & 62911,3 & 250071,2 & 100126,9 & 52449,0 & 12088,7 \\
\hline 2009 & 57843,4 & 232240,8 & 92969,5 & 52184,4 & 11262,3 \\
\hline 2008 & 60917,5 & 214424,0 & 97381,4 & 53805,5 & 10760,3 \\
\hline 2007 & 54545,1 & 229712,0 & 84784,5 & 45129,2 & 11259,5 \\
\hline 2006 & 48204,4 & 190421,5 & 70860,5 & 36148,3 & 10145,9 \\
\hline 2005 & 44445,5 & 151790,5 & 55673,0 & 35613,7 & 9507,0 \\
\hline 2004 & 40890,5 & 144708,5 & 49577,9 & - & 9500,3 \\
\hline
\end{tabular}

Źródło: opracowanie i obliczenia własne na podstawie: tabel Capital Market Size: Selected Indicators - Global Financial Stability Report (2014: 153; 2013: 169; 2012: 11; 2011: 11; 2010: 19; 2009: 183; 2008: 181; 2007: 139; 2006: 95; 2005: 17) oraz tabel The World's Top 100 Non-financial TNCs i The World's Top 50 Financial TNCs - World Investment Report (2006-2013).

Aktywność KTN na rynku międzynarodowym starano się ,wycenić” poprzez udział aktywów najpotężniejszych korporacji finansowych w wartości globalnego rynku kapitałowego (GRK) oraz udział aktywów najpotężniejszych korporacji niefinansowych w wartości globalnego PKB (GPKB). W całej dekadzie obydwa wskaźniki stale utrzymały się na poziomie ok. $20 \%$, co świadczy o potencjale KTN i ich sile oddziaływania na gospodarkę światową. W kontekście niniejszego badania istotna wydaje się ponadto kwestia udziału aktywów najpotężniejszych korporacji finansowych w ogólnych aktywach bankowych. Badanie wykazało, że między 2005 r. a 2012 r. nastąpił spadek tego udziału z 64 do 44\%, co może świadczyć o rozwoju rynków finansowych oraz pojawieniu się ,nowych” graczy spoza Top50 najpotężniejszych KTN. Aktywa bankowe wykazują w ten sposób większy stopień rozproszenia, co utrudnia monitorowanie ich przepływów i zarządzanie rynkiem. Można domniemywać, że przy równoczesnym, obserwowanym 
rozwoju powiązań sieciowych korporacje poprzez wykorzystanie swoich systemów „wewnętrznych” mogą niejako mniej oficjalnie wpływać na globalny rynek - poprzez jednostki stowarzyszone, współpracujące.

Tabela 3

Udział aktywów najpotężniejszych KTN w wartości globalnego rynku kapitałowego (finansowych) i globalnego PKB (niefinansowych) (w \%)

\begin{tabular}{|c|c|c|c|c|}
\hline Rok & $\begin{array}{c}\text { Udział aktywów } \\
\text { 100 najpotężniej- } \\
\text { szych niefinanso- } \\
\text { wych KTN } \\
\text { w globalnym PKB }\end{array}$ & $\begin{array}{c}\text { Udział aktywów } \\
\text { 50 najpotężniej- } \\
\text { szych finansowych } \\
\text { KTN } \\
\text { w globalnym rynku } \\
\text { kapitałowym }\end{array}$ & $\begin{array}{c}\text { Udział aktywów } \\
\text { 50 najpotężniej- } \\
\text { szych finansowych } \\
\text { KTN } \\
\text { w globalnych akty- } \\
\text { wach bankowych }\end{array}$ & $\begin{array}{c}\text { Udział wartości } \\
\text { globalnego } \\
\text { rynku kapitałowego } \\
\text { w globalnym PKB }\end{array}$ \\
\hline 2013 & 19,07 & 18,63 & - & 379,7 \\
\hline 2012 & 17,78 & 18,99 & 43,61 & 371,9 \\
\hline 2011 & 17,68 & 21,02 & 48,72 & 366,0 \\
\hline 2010 & 19,21 & 20,97 & 52,38 & 397,5 \\
\hline 2009 & 19,47 & 22,47 & 56,13 & 401,5 \\
\hline 2008 & 17,66 & 25,09 & 55,25 & 352,0 \\
\hline 2007 & 20,64 & 19,65 & 53,23 & 421,1 \\
\hline 2006 & 21,05 & 18,98 & 51,01 & 395,0 \\
\hline 2005 & 21,39 & 23,46 & 63,97 & 341,5 \\
\hline 2004 & 23,23 & - & - & 353,9 \\
\hline
\end{tabular}

Źródło: opracowanie własne na podstawie: tabel Capital Market Size: Selected Indicators - Global Financial Stability Report (2014: 153; 2013: 169; 2012: 11; 2011: 11; 2010: 19; 2009: 183; 2008: 181; 2007: 139; 2006: 95; 2005: 17).

Na podstawie przeprowadzonej analizy (Global Financial Stability Report 2005-2014) można ponadto stwierdzić, że wartość GRK blisko czterokrotnie przekracza GPKB, co świadczy o niezmiennie znaczącej roli międzynarodowych przepływów kapitałowych w gospodarce światowej. Udział GRK w GPKB w ostatniej dekadzie wahał się średnio od 340\% (w 2005 r.) do 420\% (w 2007 r.). W 2013 r. wskaźnik ten wyniósł 380\%, czyli znalazł się na poziomie średnim dla dekady. Najsilniejsze uzależnienie od rynków kapitałowych wykazują gospodarki będące krajami macierzystymi KTN. Wśród grup państw najwyższy był dla Unii Europejskiej 562\% (w 2013 r.) ) $^{3}$ Japonii 544\% (w 2010 r., a w 2013 r. było to 515\%), Stanów Zjednoczonych 444\% (w 2010 r., a w 2013 r. było to

${ }^{3}$ Rekordowy dla Luksemburga 3207\%, Irlandii 1168\%, Wielkiej Brytanii 808\%. Najniższy w Grecji 293\% i we Włoszech 378\%. 
414\%) ${ }^{4}$. W zestawieniu ujawnia się jednak aktywne włączanie się w działanie na rynku globalnym nowych obszarów, takich jak nowo uprzemysłowione gospodarki azjatyckie Hongkongu, Korei, Singapuru, Tajwanu (średnio 618\% udział PKB w GRK w 2013 r.). Obserwujemy także dynamiczny wzrost aktywności kapitałowej (o 24 punktów procentowych), gospodarek wschodzących (z 171\% w 2004 r. do 195\% w 2013 r.). Rekordowe wzrosty odnotować należy dla europejskich krajów tej grupy (w tym Polski) - wzrost z 72\% udziału PKB w GRK (w 2004 r.) do 123\% (w 2013 r.).

Podsumowując, ewolucja korporacji transnarodowych, wiążąca się ze wzrostem aktywów, sprzedaży, zatrudnienia oznacza dynamiczny rozwój globalnych sieci biznesowych (GSB), co umacnia KTN jako podmioty wpływające na międzynarodowe przepływy kapitału, produkcję międzynarodową, poziom kreacji produktu krajowego brutto poszczególnych państw i prowadzoną przez nie politykę (w tym dotyczącą finansów międzynarodowych) ${ }^{5}$. Warto także zwrócić uwagę, że rozwój GSB oznacza wzrost siły kapitałowej najpotężniejszych KTN - orchestratorów sieci ${ }^{6}$, który nie jest wprost widoczny w statystykach międzynarodowych, co utrudnia analizę.

\section{WPLYW ZMIANY POZYCJI KORPORACJI TRANSNARODOWYCH W GOSPODARCE ŚWIATOWEJ NA MIĘDZYNARODOWE PRZEPLYWY KAPITALU}

Analizując wpływ KTN na międzynarodowe przepływy kapitału skoncentrowano się na trzech formach przepływów: bezpośrednich inwestycjach zagranicznych (BIZ), przepływach prywatnego kapitału portfelowego (KP) oraz pozostałych prywatnych przepływach finansowych (głównie transgranicznych kredytach bankowych - TKB). Te kategorie przepływów (BIZ, KP, TKB) ${ }^{7}$ stanowią bowiem podstawowe sfery (Kłysik-Uryszek 2013: 191-193), w których wpływ zmiany

\footnotetext{
${ }^{4}$ Dla porównania w 2004 r. wynosił odpowiednio 413\% (w UE), 476\% (w Japonii), 398\% (w USA).

${ }^{5}$ Wraz z rozwojem gospodarki światowej i wzrostem stopnia jej otwarcia (globalizacja rynków, liberalizacja przepływów) korelacja między aktywnością korporacji a dynamiką zmian na rynku globalnym rośnie.

${ }^{6}$ GSB stanowią bowiem organizacje o rozwiniętej, ponadnarodowej, wielopoziomowej często nawet wielobranżowej strukturze.

${ }^{7} \mathrm{Na}$ ogół przepływów składają się: inwestycje zagraniczne; inwestycje portfelowe - transakcje dotyczące dłużnych i udziałowych papierów wartościowych, a także pochodnych instrumentów finansowych, dokonywane przez NBP, instytucje rządowe i samorządowe, sektor bankowy, pozostałe podmioty rynkowe, w tym korporacje z nierezydentami; pozostałe inwestycje zagraniczne, np. udzielone lub otrzymane kredyty bankowe, pozostałe kredyty i pożyczki, gotówka, rachunki bieżące, lokaty i depozyty oraz pozostałe należności i pasywa zagraniczne, ale także oficjalne aktywa rezerwowe.
} 
pozycji korporacji transnarodowych w gospodarce światowej może znaleźć odzwierciedlenie na międzynarodowych rynkach finansowych.

Bezpośrednie inwestycje zagraniczne są lokatą długookresową, dlatego KTN, podejmując się BIZ, dokonują najbardziej szczegółowej analizy uwarunkowań lokaty. Państwa goszczące podejmują z kolei działania na rzecz przyciągania tej formy przepływów kapitałowych. BIZ mogą pełnić kluczową rolę w procesie transferu wiedzy, umiejętności i dyfuzji technologii. Oddziaływanie KTN przez BIZ na wzrost gospodarczy zależy jednak od zdolności absorpcyjnych, czyli dostosowania inwestycji do lokalnych uwarunkowań i predyspozycji (Kolasa, Bijsterbosch 2010). Korporacje, lokując swój kapitał w formie określonego typu BIZ, wpływają znacząco na rozwój określonych sfer/obszarów/krajów/regionów. Dodatkowo podaż kapitału może również mieć istotne znaczenie dla rozwoju rynku finansowego, zwiększając jego kapitalizację, płynność oraz dostępność instrumentów finansowych, co pośrednio może także determinować wzrost gospodarczy.

W strukturze przepływów kapitałowych, generowanych przez KTN, BIZ są stale dominującym strumieniem inwestycji. Zmienia się jednak ich struktura geograficzna, co odzwierciedla wdrażanie przez KTN modelu globalnej sieci o zrównoważonych strukturach - filary regionalne. Obrazuje to chociażby rozkład lokat BIZ. W 2000 r. tylko 19\% inwestycji absorbowały kraje rozwijające się (w tym Azja w latach 2000-2010 ok. 40\%), w 2013 r. napływ BIZ do gospodarek rozwijających się osiągnął 53,6\% globalnych przepływów (wartość 778 mld USD). Osiągnięcie poziomu równowagi między grupami krajów spowodowało wyhamowanie ich tempa - spadło do $7 \%$, w porównaniu ze średnim wzrostem w ciągu ostatnich 10 lat 17\%, co potwierdza dążenie KTN do uzyskania równowagi regionalnej.

Analizując globalne przepływy BIZ jako barometr aktywności KTN na rynku międzynarodowych przepływów kapitałowych, można zauważyć, że w 2013 r. BIZ powróciły do trendu wzrostowego (wzrost o 9\%, czyli 1,45 bln USD) - osiągnęły 25,5 bln USD (World Investment Report 2014: 5-19). Sugeruje to wzrost aktywności inwestycyjnej KTN w efekcie stabilizacji sytuacji makroekonomicznej. Potwierdza to także fakt, że wzrost BIZ odnotowano we wszystkich głównych grupach gospodarek. Regionem o najwyższej dynamice pozostaje nadal Azja $^{8}$ (napływ w 2012 r. - 415 mld USD, w 2013 r. - 426 mld USD), lecz wzrosty

${ }^{8}$ Dynamika napływu kapitału do krajów rozwijających się zwiększyła się od 2003 r., co było konsekwencją czynników zwiększających popyt na kapitał na tych rynkach (rozwój lokalnych filii KTN), sprzężonych z rosnącą podażą kapitału w skali międzynarodowej. Po stronie czynników wewnętrznych, przyciągających kapitał istotne znaczenie miało m.in. podniesienie średniego tempa wzrostu gospodarczego na skutek szeregu reform strukturalnych, które zwiększały stabilność makroekonomiczną oraz perspektywy rozwoju tych krajów. W latach 2000-2011 średnioroczny wzrost realnego PKB w krajach rozwiniętych wynosił 1,8\%, natomiast w krajach rozwijających się $-6,2 \%$. W tym okresie średnioroczny wzrost realnego PKB wynosił 8,3\% w rozwijającej się Azji, 4\% w Europie Środkowej i Wschodniej, 3,5\% w Ameryce Łacińskiej i na Karaibach. 
dotyczą także krajów wysoko rozwiniętych. Napływ BIZ do krajów rozwijających się jest jednak nadal powyżej osobno rozpatrywanych obszarów zarówno UE (246 mld USD), jak i USA (250 mld USD). Aktywność KTN w postaci BIZ dla Azji jest na poziomie zbliżonym do sumy dla USA i UE. Istotne wydaje się, że przewidywana aktywność KTN na rynku międzynarodowym, mierzona wartością globalnych BIZ, będzie nadal rosnąć w kolejnych latach - odpowiednio w $2014 \mathrm{r}$. przewidywany wzrost o 1,6 bln USD, w 2015 r. - 1,75 bln USD, w 2016 r. - 1,85 bln USD. Wzrost ten będzie jednak napędzany głównie przez inwestycje w gospodarkach rozwiniętych, do których kapitał „macierzysty-KTN” powrócił po zawirowaniach kryzysowych. Zjawiskami, które mogą wyhamować oczekiwane ożywienie globalnych przepływów BIZ, jest z kolei „kruchość” niektórych rynków wschodzących oraz rosnące zagrożenia związane z niepewnością polityczną i konfliktami regionalnymi. Po kryzysie KTN wdrożył bowiem procedury ostrożnościowe, które mają zabezpieczyć je przed nadmiernym ryzykiem inwestycyjnym (co może spowodować omijanie obszarów „niepewnych inwestycji”).

Konkludując, wydaje się, że geograficzna struktura rozkładu BIZ będzie dążyć do zrównoważonego wzoru poprzez zwiększający się ponownie udział krajów rozwiniętych $w$ globalnych przepływach inwestycyjnych. Prognoza UNCTAD przewiduje, że w 2016 r. będzie to 52\% do 48\% (World Investment Report 2014, wykres 1.22 ). Na rzecz takiego modelu przemawiają analizy strategii najpotężniejszych korporacji, w których potwierdza się model kreacji globalnych sieci biznesowych opartych na stabilnych filarach regionalnych oligopoli (Rosińska-Bukowska 2012: 248-315). Badania wskazują ponadto, że obecnie korporacje podejmują inwestycje, uwzględniając coraz szerszy wachlarz uwarunkowań endo- i egzogenicznych ${ }^{10}$ (NBP 2012: 6-8; Śliwiński 2011: 133-135) w tym np. stosowane regionalne regulacje fiskalne między państwami goszczącymi a krajami pochodzenia KTN (Ahrend, Goujard 2012: 15-16). Tym samym należy dostrzec, że KTN (co może być zaskakujące), wdrażając swoje strategie, mogą pełnić w pewnym zakresie rolę stabilizatorów rynków międzynarodowych, przynajmniej w sferze przepływów o charakterze BIZ.

Korporacje dokonują także inwestycji portfelowych - zwłaszcza korporacje finansowe. Ten typ inwestycji jest z kolei znacznie bardziej zmienną, wrażliwą na wstrząsy na międzynarodowych rynkach finansowych, a czasem nawet drobne impulsy i pogłoski, formą przepływów kapitałowych. Obserwując zmiany

9 Wzrosły także BIZ w innych dużych regionach rozwijających się: w Afryce (o 4\%), Ameryce Łacińskiej i na Karaibach (wzrost o 6\%, z wyłączeniem centrów finansowych offshore).

${ }^{10}$ Czynniki egzogeniczne decydują o kierunku przepływów kapitału w skali globalnej i związane są z ogólną sytuacją w gospodarce światowej, w szczególności w krajach/podmiotach, eksportujących kapitał; są to m.in.: szoki globalne w zakresie ryzyka, płynności, ceny aktywów. Czynniki endogeniczne to wewnętrzne cechy danej gospodarki/miejsca, mogące stanowić determinanty wielkości i struktury napływu kapitału z uwagi na specyficzne cechy danego kraju/regionu, takie jak np. jakość instytucji, rating, czynniki fundamentalne. 
międzynarodowych przepływów kapitału portfelowego (KP) w latach 20002011, ze szczególnym uwzględnieniem okresu kryzysu, można dokonać analizy pod kątem wpływu konkretnego czynnika na te obroty. W tab. 4 zaprezentowano wartości, oznaczające procent zmian przepływów, objaśniany przez czynniki endo- i egzogeniczne w odniesieniu do grup krajów.

Tabela 4

Czynniki endo- i egzogeniczne oddziaływujące na międzynarodowe przepływy kapitału portfelowego (specyfika dla grup krajów)

\begin{tabular}{|l|c|c|c|c|c|c|}
\hline \multirow{2}{*}{\multicolumn{1}{|c|}{ Grupy krajów }} & \multicolumn{2}{|c|}{ Czynniki egzogeniczne } & \multicolumn{2}{c|}{ Czynniki endogeniczne } \\
\cline { 2 - 7 } & $\begin{array}{c}\text { przed } \\
\text { kryzysem }\end{array}$ & kryzys & $\begin{array}{c}\text { po } \\
\text { kryzysie }\end{array}$ & $\begin{array}{c}\text { przed } \\
\text { kryzysem }\end{array}$ & kryzys & $\begin{array}{c}\text { po } \\
\text { kryzysie }\end{array}$ \\
\hline $\begin{array}{l}\text { Wszystkie kraje } \\
\text { (próba 50 państw) }\end{array}$ & 65,4 & 72,8 & 45,0 & 34,6 & 27,2 & 55,0 \\
\hline $\begin{array}{l}\text { Europa - UE } \\
\text { (kraje wysoko rozwinięte) }\end{array}$ & 90,8 & 23,2 & 84,2 & 9,2 & 76,8 & 15,8 \\
\hline $\begin{array}{l}\text { Europa } \\
\text { (gospodarki wschodzące) }\end{array}$ & 86,6 & 93,2 & 80,3 & 13,4 & 6,8 & 19,7 \\
\hline $\begin{array}{l}\text { Inne gospodarki rozwinięte } \\
\text { w tym USA }\end{array}$ & 76,1 & 80,5 & 58,8 & 23,9 & 19,5 & 41,2 \\
\hline Azja & 48,3 & 84,9 & 18,1 & 51,7 & 15,1 & 81,9 \\
\hline Ameryka Łacińska & 48,6 & 150,0 & 36,9 & 51,2 & $-50,0$ & 63,1 \\
\hline Afryka i Bliski Wschód & 109,3 & 104,4 & 54,8 & $-9,3$ & $-4,4$ & 45,2 \\
\hline
\end{tabular}

„Przed kryzysem” - 1.05.2005-7.08.2007; „kryzys” - 8.08.2007-15.03.2009; „po kryzysie” - 16.03.2009-31.10.2010. Wartości ujemne oznaczają, że czynniki przyciągające, ceteris paribus, powinny sprzyjać napływowi kapitału, jednak kraje doświadczały odpływu kapitału na skutek dominacji czynników zewnętrznych.

Źródło: Fratzscher, Lo Duca, Straub (2012; 2013); NBP (2012, tab. 1.2).

$\mathrm{Na}$ podstawie analizy wyników badań można zauważyć istotne zmiany w czynnikach, kształtujących przepływy KP. Postępująca integracja finansowa sprawiła, że głównymi determinantami przepływu kapitału w krótkim okresie stały się czynniki egzogeniczne, czyli w znacznej mierze pozostające poza bezpośrednim wpływem kraju przyjmującego kapitał. KTN, wykorzystując swoje globalne, wielopoziomowe struktury, starały się „omijać” niedogodności sytuacji rynkowej. Szczególnie wyraźnie można było to obserwować w okresie kryzysu. Bazując na zakładanej wówczas ,izolacji” krajów rozwijających się i możliwości uniknięcia w ten sposób negatywnych konsekwencji problemów, pojawiających się na rynkach krajów rozwiniętych, korporacje zintensyfikowały ekspansję zwłaszcza 
azjatycką. Wyraźny napływ kapitału trwał od początku 2007 r. do połowy 2008 r. Następnie (druga połowa 2008-2009) obserwujemy gwałtowny spadek napływu kapitału na te rynki, podobnie jak w drugiej połowie 2011 r. - powrót korporacji do bezpiecznych aktywów ${ }^{11}$ (Qureshi i in. 2011). Wnioski istotne dla niniejszych rozważań to wyraźny spadek wpływu państw narodowych na tego typu przepływy, głównie w okresach zawirowań na rynkach finansowych oraz aktywizacja KTN oparta na eksploatacji globalnych systemów sieciowych.

Trzecia $\mathrm{z}$ form międzynarodowego przepływu kapitału, czyli transgraniczne kredyty bankowe, to szybko rosnący strumień inwestycji we współczesnej gospodarce, co można uznać za wyraźny dowód ekspansji kapitałowej korporacji. Rozwój sektora finansowego w krajach rozwijających, a także otwarcie na napływ kapitału zagranicznego stanowiły impulsy dla transgranicznej własności aktywów bankowych. Spowodowało to znaczący wzrost udziału TKB w strukturze przepływów w latach 2007-2009 do rekordowych poziomów - ok. 20\% (NBP 2012, wykres 1.9: 20). Powiązania korporacyjne (struktura własnościowa największych banków) wyhamowały ponadto w okresie kryzysu odpływ kapitału z gospodarek rozwijających się, zwłaszcza nowych państw członkowskich Unii Europejskiej pozostających poza strefą euro (Herrmann, Mihaljek 2010; Vogel, Winkler 2011). Odpływ TKB z obszarów niepowiązanych kapitałowo z korporacjami był z kolei silniejszy od odpływu KP. Na mocy tzw. Inicjatywy Wiedeńskiej (2009) najpotężniejsze korporacje finansowe - banki macierzyste - zobowiązały się bowiem zapewnić stabilność funkcjonowania sektora bankowego w nowych krajach członkowskich UE, w tym nie wycofywać kapitału z tych rynków. Potwierdza to postępujący proces delewarowania sektora finansowego w skali globalnej w okresie kryzysu, przy uwzględnieniu roli KTN jako stabilizatorów rynku (NPB 2012: 21-22). Stanowi jednocześnie wyraźny dowód wpływu korporacji na międzynarodowe przepływy kapitału.

Konkludując, w statystykach bilansu płatniczego przepływy kapitałowe dzieli się na bezpośrednie inwestycje zagraniczne, inwestycje portfelowe oraz pozostałe inwestycje (Oziewicz, Michałowski 2012). We wszystkich tych kategoriach inwestycje dokonywane przez korporacje transnarodowe odgrywają znaczącą rolę. Tym samym wpływ pozycji KTN w gospodarce światowej na strukturę i kierunki międzynarodowych przepływów kapitałowych wydaje się oczywisty. Kapitalne znaczenie ma dostrzeżenie, że oddziaływanie to wcale nie musi przybierać formy bezpośredniej, ale może dotyczyć uzyskania wpływu na innych uczestników rynku globalnego i kształtowania ich aktywności na rynku kapitałowym.

Największy wpływ na rozwój globalnego rynku finansowego miała bowiem liberalizacja przepływów kapitałowych. Stopniowa likwidacja ograniczeń

${ }^{11}$ Nasilający się kryzys fiskalny i problemy sektora bankowego w strefie euro oraz obniżenie ratingu dla USA (sierpień 2011 r.) spowodowały wzrost awersji do ryzyka, a w efekcie odpływ kapitału z rynków rozwijających się (druga połowa 2011 r.). 
swobodnego przepływu kapitału pomiędzy krajami obejmowała m.in. zniesienie ograniczeń dotyczących bezpośrednich inwestycji zagranicznych oraz wymiany towarów i usług z nierezydentami. Zrozumienie konsekwencji, jakie przyniosły te zmiany, wydaje się fundamentem wyjaśniania procesów zachodzących na międzynarodowych rynkach finansowych - wskazuje bowiem wprost na wzrost roli KTN w systemie globalnym i konieczność uwzględniania korporacji jako istotnych graczy globalnego rynku finansowego.

Wydaje się, że z punktu widzenia niniejszej analizy kluczowe znaczenie ma podkreślenie stałego charakteru rosnącej współzależności między rynkami finansowymi a realną gospodarką (niebędącego jedynie pochodną stanu koniunktury, efektem bieżących impulsów), ale wynikającego z nieustannego procesu pogłębiania stopnia internacjonalizacji biznesu i globalizacji rynków. W konsekwencji można uznać, że rozwój międzynarodowych rynków finansowych, wymagający ciągłego wzrostu płynności aktywów na rynku międzynarodowym, jest ścisłe powiązany z aktywnością przepływów generowanych w wyniku działalności korporacji transnarodowych. Tym samym wskaźnik korelacji między aktywnością KTN a zmianami na międzynarodowych rynkach finansowych stale wzrasta. Siła oddziaływania KTN na system gospodarki światowej wynika ponadto ze ,zrastania” się (m.in. w wyniku realizacji strategii rozwoju przez KTN) poszczególnych segmentów rynku finansowego (kapitałowego, pieniężnego, ubezpieczeniowego, instrumentów pochodnych), dotychczas rozłącznych. W efekcie, poprzez rozwijanie przez KTN wielopoziomowych systemów powiązań - czyli kreowanie GSB, rozmiar międzynarodowych rynków finansowych jest coraz bardziej znaczący, a dynamika stale przekracza wzrost światowego PKB (Chrabonszczewska, Waszkiewicz 2010: 4-6, 46).

W 2003 r. międzynarodowe rynki finansowe widziane jako suma kapitalizacji giełdowej, obligacji, aktywów bankowych, czyli według modelu Global Stability Report IMF, stanowiły 130341 mld USD, a globalne PKB 36320 mld USD, w 2007 r. odpowiednio rynki 241089 mld USD a PKB 54841 mld USD, a w 2013 r. proporcja ta wynosiła już 272769 do 72106 mld USD. Relacja wartości światowych rynków finansowych do światowego PKB stale utrzymuje się w przedziale 3,5-4 krotności GRK do GPKB. Przykładowo: 358\% w 2003 r., 341\% w 2005 r., $421 \%$ w 2007 r., $401 \%$ w 2009 r., 366\% w 2011 r., 380\% w 2013 r. Należy dodać, że obszary krajów wysoko rozwiniętych, w tym głównie państw Unii Europejskiej, Stanów Zjednoczonych i Japonii, są znacznie silniej „uzależnione od kaprysów" rynku kapitałowego niż słabiej rozwinięte gospodarki (wyjątek nowo uprzemysłowione kraje azjatyckie: Hongkong, Korea, Singapur, Tajwan - udział PKB w GRK przekracza 600\%).

Podsumowując, w badanym okresie 2003-2013, a zwłaszcza w latach 20072013, nastąpiły nie tylko istotne zmiany rozmiaru globalnego rynku finansowego, lecz także zmiany jego struktury geograficznej i proporcji poszczególnych segmentów (Chrabonszczewska i in. 2012). Wydaje się, że jest to konsekwencją 
globalnego kryzysu finansowego, a w jego efekcie przynajmniej częściowo wynika z adekwatnej aktywności korporacji, które dokonywały ,przesunięć” kapitału w ramach swoich struktur. Oznacza to nacisk na rolę czynników egzogenicznych jako głównych determinant kształtowania kierunków i struktury obrotów na międzynarodowych rynkach.

\section{ZAKOŃCZENIE}

W artykule podjęto próbę zwrócenia uwagi na systematycznie rosnącą rolę korporacji transnarodowych $\mathrm{w}$ gospodarce światowej i zakresu ich wpływów, co ma istotne znaczenie dla kreowania globalnych przepływów kapitałowych. Postawiono tezę, że konsekwencją rosnącej siły kapitałowej KTN jest osłabienie siły oraz zakresu możliwości oddziaływania państw na międzynarodowe rynki finansowe. To z kolei powoduje wzrost wrażliwości realnej gospodarki na impulsy i „zawirowania” w świecie finansów międzynarodowych, a zatem uzależnia ją coraz silniej od kondycji i struktury rynku finansowego. Wskazano, że 100 najpotężniejszych niefinansowych korporacji dysponuje aktywami stanowiącymi ok. $20 \%$ globalnego PKB, a $50 \mathrm{KTN}$ finansowych ok. 20\% wartości globalnego rynku kapitałowego, co wskazuje, że KTN są podmiotami wpływającymi znacząco na strukturę obrotów i kierunki przepływów we współczesnej gospodarce. W konsekwencji powinny być uwzględniane jako członkowie zespołu do spraw stabilizacji i kontroli nad międzynarodowymi rynkami finansowymi.

"Globalna architektura finansowa” zakłada jednak konstruktywną współpracę tradycyjnych instytucji z Bretton Woods tj. Międzynarodowego Funduszu Walutowego i Banku Światowego, OECD, Banku Rozrachunków Międzynarodowych, Międzynarodowej Organizacji Nadzoru nad Papierami Wartościowymi, Międzynarodowej Organizacji Nadzoru nad Ubezpieczeniami, a także rządów i parlamentów poszczególnych krajów. Istotną rolę w jej tworzeniu spełniają także m.in. grupy G3, G7, G10, G20. Ponadto uczestniczy w niej wiele mniej „formalnych instytucji”, tworzących tzw. miękkie prawo w formie standardów, zaleceń, regulacji postępowania i wskazówek (Waściński, Wójcik 2011: 15-23). W tym złożonym gronie wydaje się jednak brakować „oficjalnej delegacji” podmiotów, dokonujących implementacji tych szczytnych zaleceń, które są aktywnymi graczami międzynarodowego rynku finansowego - czyli najpotężniejszych korporacji transnarodowych. Być może fakt ten powoduje, że wielokrotne wdrożenie nawet słusznych projektów spotyka się z „oporem rynku”. Wydaje się, że nie czyniąc KTN oficjalnymi architektami międzynarodowego rynku finansowego, odpowiedzialnymi za jego koordynację oraz system regulacji, trudno będzie osiągnąć państwom i ich organizacjom zamierzone cele. Postulat ten to wskazanie na potrzebę realizacji modelu zarządzania partycypacyjnego na międzynarodowych rynkach finansowych. 


\section{BIBLIOGRAFIA}

Ahrend R., Goujard A. (2012), International capital mobility and financial fragility: Part 3: How do structural policies affect financial crisis risk? Evidence from past crises across ORCD and emerging economics, „Economics Department Working Papers”, No. 966, ECO/WKP 2012/43.

Boruc R., Remisiewicz M. (1999), Parada gigantów, „Wprost”, nr 2 (841), s. 62.

Chrabonszczewska E., Miklaszewicz S., Sum K., Waszkiewicz A. (2012), Międzynarodowe rynki finansowe po kryzysie, Oficyna Wydawnicza SGH, Warszawa.

Chrabonszczewska E., Waszkiewicz A. (2010), Ryzyko na międzynarodowych rynkach finansowych, „Prace Naukowe Instytutu Gospodarki Światowej”, nr 302, s. 1-47.

Dunning J. H. (2001), The Eclectic (OLI) Paradigm of International Production: Past, Present and Future, „International Journal of the Economics of Business”, Vol. 8, No. 2, s. 173-190.

Forbes Global 2000 (2013), The World Biggest Public Companies, www.forbes.com/global2000/ list [21.05.2016].

Fratzscher M., Lo Duca M., Straub R. (2012), Quantitative Easing, Portfolio Choice and International Capital Flows, www.cass.city.ac.uk/_data/assets/pdf_file/0009/127476/Lo-Duca.pdf (dostęp: 12.03.2014).

Fratzscher M., Lo Duca M., Straub R. (2013), On the international spillovers of US Quantitative, „Working Paper European Central Bank”, Serie S, No. 1557, June.

Gasz M. (2012), Znaczenie korporacji transnarodowych w gospodarce światowej, „Ekonomia i Prawo", nr 4, t. IX, s. 29-45.

Global Financial Stability Report (2005), International Monetary Fund, http://www.imf.org/exter$\mathrm{nal} / \mathrm{pubs} / \mathrm{ft} / \mathrm{gfsr} / 2005 / 01 /$ (dostęp: 21.05.2016).

Global Financial Stability Report (2006), International Monetary Fund, http://www.imf.org/External/Pubs/FT/GFSR/2006/01/ (dostęp: 21.05.2016).

Global Financial Stability Report (2007), International Monetary Fund, https://www.imf.org/External/Pubs/FT/GFSR/2007/01/pdf/text.pdf (dostęp: 21.05.2016).

Global Financial Stability Report (2008), International Monetary Fund, https:/www.imf.org/exter$\mathrm{nal} / \mathrm{pubs} / \mathrm{ft} / \mathrm{gfsr} / 2008 / 01 /$ (dostęp: 21.05.2016).

Global Financial Stability Report (2009), International Monetary Fund, https://www.imf.org/External/Pubs/FT/GFSR/2009/01/pdf/text.pdf (dostęp: 21.05.2016).

Global Financial Stability Report (2010), International Monetary Fund, https://www.imf.org/external/pubs/ft/gfsr/2010/02/ (dostęp: 21.05.2016).

Global Financial Stability Report (2011), International Monetary Fund, http://www.imf.org/external/pubs/ft/gfsr/2011/01/ (dostęp: 21.05.2016).

Global Financial Stability Report (2012), International Monetary Fund, http://www.imf.org/exter$\mathrm{nal} / \mathrm{pubs} / \mathrm{ft} / \mathrm{gfsr} / 2012 / 01 /$ (dostęp: 21.05.2016).

Global Financial Stability Report (2013), International Monetary Fund, http://www.imf.org/External/Pubs/FT/GFSR/2013/02/ (dostęp: 21.05.2016).

Global Financial Stability Report (2014), International Monetary Fund, http://www.imf.org/exter$\mathrm{nal} / \mathrm{pubs} / \mathrm{FT} / \mathrm{GFSR} / 2014 / 01 /$ index.htm (dostęp: 21.05.2016).

Gwiazda A. (2000), Globalizacja i regionalizacja gospodarki światowej, Wydawnictwo A. Marszałek, Toruń.

Herrmann S., Mihaljek D. (2010), The determinants of cross-border bank flows to emerging markets: new empirical evidence on the spread of financial crises, „BIS Working Papers”, No. 315, July.

Kłysik-Uryszek A. (2013), Ścieżka rozwoju inwestycji (koncepcja IDP) doświadczenia Polski, „Przegląd Zachodniopomorski”, z. 3, t. 2, s. 187-200. 
Kogut B., Zander U. (2003), Knowledge of the Firm and the Evolutionary Theory of Multinational Corporation, „Journal of International Business Studies”, Vol. 34, s. 516-529.

Kolasa M., Bijsterbosch M. (2010), FDI and productivity convergence in Central and Eastern Europe: an industry level investigation, „Review World Economy”, No. 145.

Kolka M. A. (2010), Korporacje transnarodowe - ich znaczenie w erze globalizacji, http://globaleconomy.pl/content/view/1774/24 (dostęp: 7.10.2010).

NBP (2012), Przepływy kapitału $w$ krajach rozwijajacych się $w$ latach 2000-2011, NBP Instytut Ekonomiczny, Warszawa, s. 1-60.

Oziewicz E., Michałowski, T. (red.), (2012), Międzynarodowe stosunki gospodarcze, PWE, Warszawa.

Piórko K. (2008), ,, Władza” korporacji transnarodowych $w$ stosunkach międzynarodowych, Wydawnictwo Grado, Torun 2008.

Rosińska-Bukowska M. (2009), Rola korporacji transnarodowych w procesach globalizacji, Dom Wydawniczy Duet, Toruń.

Rosińska-Bukowska M. (2012), Rozwój globalnych sieci biznesowych jako strategia konkurencyjna korporacji transnarodowych, Wydawnictwo Uniwersytetu Łódzkiego, Łódź.

Śliwiński P. (2011), Przepływy kapitału międzynarodowego a wzrost gospodarczy w krajach Europy Środkowo-Wschodniej w latach 1994-2008, Wydawnictwo Uniwersytetu Ekonomicznego w Poznaniu, Poznań.

Qureshi M. S., Ostry J. D., Ghosh A. R., Chamon M. (2011), Managing Capital Inflows: The Role of Capital Controls and Prudential Policies, „NBER Working Paper”, No. 17363, August, National Bureau of Economic Research.

Waściński T., Wójcik G. P. (2011), Kierunki rozwoju rynku finansowego po kryzysie, „Zeszyty Naukowe Uniwersytetu Przyrodniczo-Humanistycznego w Kielcach”, nr 88, seria: Administracja i Zarządzanie (15), s. 15-23.

World Investment Report (2004), The Shift Towards Services, www.unctad.org (dostęp: 21.05.2016).

World Investment Report (2005), Transnational Corporation and the Internationalization of $R \& D$ www.unctad.org (dostęp: 21.05.2016).

World Investment Report (2006), FDI from Developing and Transition Economies: Implications for Development, www.unctad.org (dostęp: 21.05.2016).

World Investment Report (2007), Transnational Corporations, Extractive, Industries and Development, www.unctad.org (dostęp: 21.05.2016).

World Investment Report (2008), Transnational Corporations and the Infrastructure Challenge, www.unctad.org (dostęp: 21.05.2016).

World Investment Report (2009), Transnational Corporations, Agricultural Production and Development, www.unctad.org (dostęp: 21.05.2016).

World Investment Report (2010), Investing in the Low-carbon Economy, www.unctad.org (dostęp: 21.05.2016).

World Investment Report (2011), Non-Equity Modes of International Production and Development, www.unctad.org (dostęp: 21.05.2016).

World Investment Report (2012), Towards a New Generation of Investment Policies, www.unctad. org (dostęp: 21.05.2016).

World Investment Report (2013), Global Value Chains: Investment and Trade for Development, www.unctad.org (dostęp: 21.05.2016).

World Investment Report (2014), Investing in the SDGs: An Action Plan, www.unctad.org (dostęp: 21.05.2016).

Vogel U., Winkler A. (2011), Cross-border bank flows and foreign banks in the global financial crisis - is Eastern Europe different?, Presentation at 3rd EMG Conference on Emerging Markets Finance Cass Business School, London.

Zimny Z., (2015), Światowy Raport Inwestycyjny 2015. Reforma zarządzania światowymi finansami. Prezentacja 24.06.2015, http://www.paiz.gov.p1/20150624/ (dostęp: 21.05.2016). 


\title{
Magdalena Rosińska-Bukowska
}

\section{CHANGING THE POSITION OF TRANSNATIONAL CORPORATIONS IN THE GLOBAL ECONOMY - IMPLICATIONS FOR INTERNATIONAL FINANCIAL MARKETS}

\begin{abstract}
The article shows changing the position of transnational corporations (TNCs) in the global economy. The article make an attempt to assess the impact of the increasing role of TNCs in the global flows of capital and the consequences of this fact for the international financial markets. The article consists of three parts. The first part - the evolution of transnational corporations as a basis for obtaining a strong position in the global economy. The second part - the analysis of the potential of the most powerful transnational corporations against the background of GDP of countries and the global capital market value. The third part - an attempt to assess the impact of corporations on international capital flows and functioning of financial markets.

Keywords: transnational corporations, TNC, globalization, foreign direct investment, FDI, portfolio investment, global economy.
\end{abstract}

